\title{
Inshore Exploitation of Atlantic Cod, Gadus morhua, in Labrador and Eastern Newfoundland Waters
}

\author{
Allenby T. Pinhorn \\ Department of Fisheries and Oceans, Fisheries Research Branch \\ Northwest Atlantic Fisheries Centre, P. O. Box 5667 \\ St. John's, Newfoundland, Canada A1C 5X1
}

\begin{abstract}
Cohort analysis of the numbers by age-group of Atlantic cod caught off southern Labrador and eastern Newfoundland during 1961-80 were used, together with certain assumptions on inshore migration of cod and the seasonal nature of the offshore and inshore fisheries, to estimate rates of inshore exploitation of the stock during 1961-76. The results indicated that during 1961-74 only a small proportion (about $5 \%$ ) of the cod, which survived the offshore fishery each year, were actually caught in the inshore fishery in the same year, although the proportions were higher in 1975 and 1976. Factors affecting the annual inshore migration of cod and the estimation of inshore exploitation rates are discussed.
\end{abstract}

\section{Introduction}

It has long been recognized that cod off Labrador and eastern Newfoundland undergo an annual cycle of inshore-offshore migrations (Templeman and Fleming, 1956; Templeman, 1962, 1965, 1966; Hodder, 1965). This migration pattern was subsequently confirmed by extensive tagging studies (Templeman, 1979; Lear 1982). These cod live in deep warm-water areas of the continental shelf and slope during winter and early spring when the prespawning and spawning concentrations support a lucrative offshore fishery by otter trawlers. In the spring with the warming of surface water, they migrate to coastal waters where they support an inshore fishery by codtraps, line gears and gillnets. With the cooling of the water in autumn, the cod move progressively deeper and ultimately retreat to their overwintering areas on the continental shelf and slope, thus completing the annual cycle.

For statistical and management purposes, the Labrador-East Newfoundland cod stock occupies the region composed of NAFO Divisions $2 \mathrm{~J}, 3 \mathrm{~K}$ and $3 \mathrm{~L}$, extending from southern Labrador to the northern part of the Grand Bank (Fig. 1). In this paper, the technique of cohort analysis (Pope, 1972) is utilized, together with certain assumptions, to partition the fishery into offshore and inshore seasonal components and thus obtain "rates of inshore exploitation", which represent the actual numbers of fish caught in the inshore fishery relative to the numbers remaining in the population at the end of the offshore fishery in each year.

\section{Materials and Methods}

The basic data used for this analysis are the estimated numbers of cod by age-group in the nominal catches of the offshore and inshore fisheries during 1961-76 (Table 1), the numbers by age-group in the population at the beginning of each year (Table 2), and the total fishing mortality coefficients by age-group (Table $3 \mathrm{~A}$ ), the latter two matrices being derived from cohort analysis of 1961-80 catch-at-age data by Wells (MS 1981). Data for 1977-80 were not included in this study because the results from cohort analysis are not reliable for 3-4 years prior to the final year (1980) of input data (Pope, 1972).

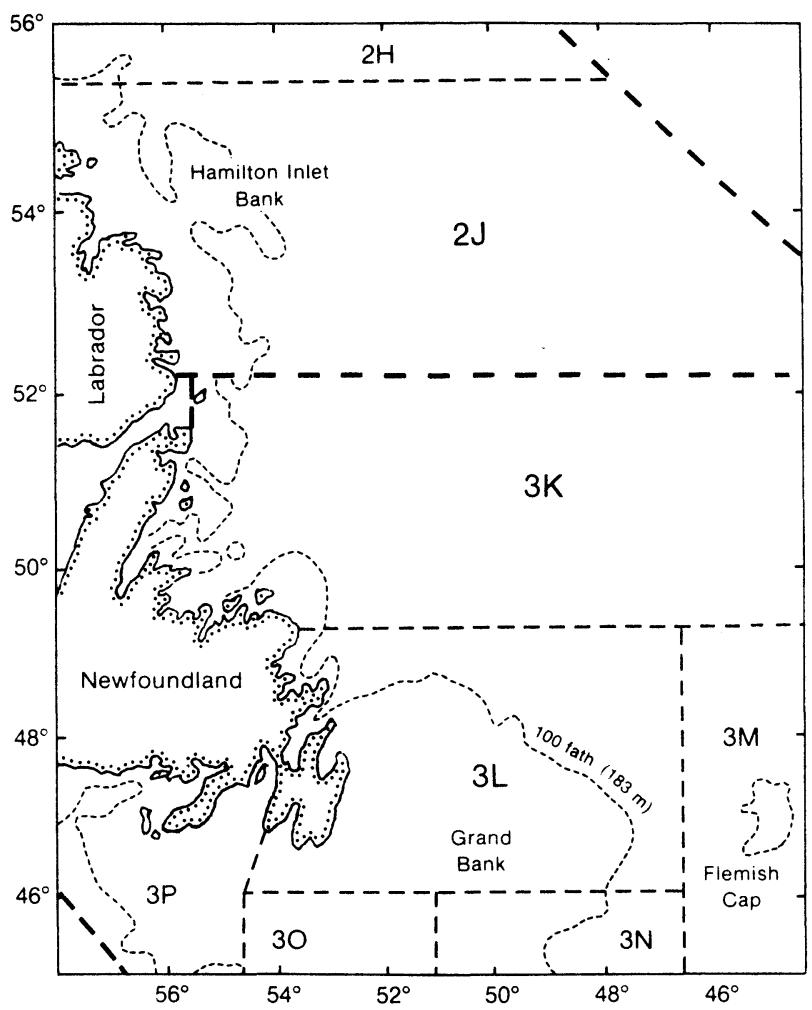

Fig. 1. Map showing NAFO Divisions referred to in the text. 
TABLE 1. Estimated numbers of cod by age-group in the nominal catches from the offshore and inshore fisheries of the Labrador-East Newfoundland region (NAFO Div. $2 \mathrm{~J}+3 \mathrm{KL}$ ), 1961-76. (Offshore fishery is defined as that by otter and pair trawls; inshore fishery is that by all other gears.)

\begin{tabular}{|c|c|c|c|c|c|c|c|c|c|c|c|c|}
\hline \multirow[b]{2}{*}{ Year } & \multirow[b]{2}{*}{4} & \multicolumn{10}{|c|}{ Numbers of cod $\left(10^{3}\right)$ by age-group } & \multirow[b]{2}{*}{ Total } \\
\hline & & 5 & 6 & 7 & 8 & 9 & 10 & 11 & 12 & 13 & $>13$ & \\
\hline \multicolumn{13}{|c|}{ Offshore fishery } \\
\hline 1961 & 20,315 & 29,100 & 45,871 & 39,033 & 30,959 & 26,675 & 19,839 & 11,284 & 10,447 & 8,436 & 12,406 & 254,365 \\
\hline 1962 & 18,550 & 43,788 & 49,683 & 39,523 & 24,483 & 17,092 & 15,704 & 8,767 & 7,855 & 6,854 & 17,230 & 249,529 \\
\hline 1963 & 20,522 & 44,333 & 89,262 & 45,914 & 21,440 & 11,588 & 8,690 & 6,474 & 3,169 & 3,005 & 7,957 & 262,354 \\
\hline 1964 & 16,391 & 41,337 & 49,161 & 85,696 & 44,072 & 15,838 & 9,910 & 6,915 & 4,921 & 4,051 & 8,554 & 286,846 \\
\hline 1965 & 18,710 & 33,513 & 55,842 & 57,194 & 58,869 & 30,577 & 12,209 & 5,748 & 2,813 & 3,107 & 8,286 & 286,868 \\
\hline 1966 & 51,540 & 80,145 & 53,425 & 53,674 & 27,857 & 20,245 & 7,211 & 3,128 & 1,444 & 1,205 & 2,743 & 302,617 \\
\hline 1967 & 67,077 & 87,368 & 86,579 & 50,571 & 34,372 & 15,603 & 13,503 & 5,028 & 2,525 & 1,652 & 2,024 & 366,302 \\
\hline 1968 & 73,084 & 177,680 & 135,555 & 76,589 & 35,716 & 21,033 & 6,959 & 4,647 & 2,905 & 1,414 & 1,990 & 537,572 \\
\hline 1969 & 26,210 & 75,309 & 143,330 & 96,205 & 46,830 & 16,982 & 10,921 & 5,301 & 3,860 & 2,544 & 2,506 & 429,998 \\
\hline 1970 & 43,578 & 65,035 & 83,341 & 74,907 & 25,387 & 9,153 & 2,782 & 1,408 & 845 & 308 & 379 & 307,123 \\
\hline 1971 & 61,302 & 80,915 & 89,106 & 51,910 & 21,977 & 10,172 & 3,707 & 1,847 & 1,048 & 969 & 1,617 & 324,570 \\
\hline 1972 & 64,137 & 105,268 & 69,188 & 52,303 & 27,321 & 10,700 & 5,757 & 2,634 & 1,491 & 1,222 & 2,727 & 342,748 \\
\hline 1973 & 33,750 & 84,931 & 56,514 & 33,519 & 25,769 & 12,974 & 7,027 & 3,464 & 1,936 & 1,058 & 849 & 261,791 \\
\hline 1974 & 7,461 & 29,057 & 70,172 & 59,209 & 34,548 & 17,867 & 9,837 & 5,375 & 2,793 & 943 & 1,662 & 238,924 \\
\hline 1975 & 6,580 & 19,760 & 30,749 & 36,139 & 34,337 & 12,163 & 6,951 & 2,159 & 1,134 & 810 & 570 & 151,352 \\
\hline 1976 & 48,982 & 23,998 & 20,209 & 15,104 & 12,927 & 10,528 & 4,000 & 1,516 & 556 & 294 & 366 & 138,480 \\
\hline \multicolumn{13}{|c|}{ Inshore fishery } \\
\hline 1961 & 11,953 & 16,592 & 12,591 & 6,312 & 3,944 & 2,805 & 2,330 & 1,512 & 1,578 & 1,340 & 1,959 & 64,916 \\
\hline 1962 & 8,132 & 22,032 & 10,290 & 9,112 & 3,906 & 3,656 & 2,895 & 2,000 & 1,900 & 1,184 & 4,843 & 69,950 \\
\hline 1963 & 6,547 & 14,840 & 26,602 & 11,961 & 7,320 & 3,598 & 2,681 & 1,587 & 948 & 850 & 2,839 & 79,773 \\
\hline 1964 & 10,285 & 14,984 & 9,796 & 12,354 & 5,753 & 4,353 & 1,882 & 1,518 & 1,190 & 760 & 3,337 & 66,212 \\
\hline 1965 & 9,324 & 12,120 & 9,639 & 5,668 & 8,327 & 2,776 & 2,465 & 1,097 & 869 & 774 & 2,083 & 55,052 \\
\hline 1966 & 14,750 & 14,089 & 9,796 & 6,097 & 2,799 & 3,800 & 1,617 & 1,524 & 810 & 631 & 1,754 & 57,667 \\
\hline 1967 & 11,373 & 13,536 & 10,625 & 4,681 & 4,448 & 1,587 & 2,600 & 934 & 835 & 461 & 1,276 & 52,356 \\
\hline 1968 & 18,522 & 21,364 & 9,443 & 4,313 & 2,175 & 1,398 & 688 & 727 & 457 & 488 & 1,124 & 60,699 \\
\hline 1969 & 11,888 & 21,057 & 10,040 & 4,440 & 2,512 & 1,288 & 619 & 701 & 330 & 276 & 747 & 53,998 \\
\hline 1970 & 13,650 & 12,276 & 10,620 & 3,882 & 1,486 & 828 & 794 & 468 & 284 & 170 & 548 & 45,006 \\
\hline 1971 & 7,744 & 11,135 & 5,311 & 3,789 & 2,142 & 1,125 & 603 & 296 & 193 & 128 & 518 & 32,384 \\
\hline 1972 & 15,663 & 11,332 & 7,012 & 3,697 & 2,279 & 1,100 & 643 & 366 & 209 & 178 & 273 & 42,752 \\
\hline 1973 & 6,913 & 9,581 & 2,727 & 1,804 & 1,500 & 1,198 & 555 & 373 & 232 & 122 & 369 & 25,374 \\
\hline 1974 & 6,339 & 6,443 & 4,528 & 2,091 & 1,552 & 733 & 363 & 125 & 107 & 57 & 138 & 22,476 \\
\hline 1975 & 8,383 & 6,149 & 3,980 & 2,719 & 1,283 & 1,174 & 735 & 239 & 129 & 69 & 94 & 24,954 \\
\hline 1976 & 15,405 & 10,616 & 4,902 & 2,875 & 1,939 & 769 & 470 & 358 & 138 & 118 & 178 & 37,768 \\
\hline
\end{tabular}

TABLE 2. Population numbers of cod by age-group in NAFO Div. $2 \mathrm{~J}+3 \mathrm{KL}$ at the beginning of the year, as estimated by cohort analysis, 1961-76.

\begin{tabular}{|c|c|c|c|c|c|c|c|c|c|c|c|}
\hline \multirow[b]{2}{*}{ Year } & \multicolumn{10}{|c|}{ Numbers of cod $\left(10^{5}\right)$ by age-group } & \multirow[b]{2}{*}{ Total } \\
\hline & 4 & 5 & 6 & 7 & 8 & 9 & 10 & 11 & 12 & 13 & \\
\hline 1961 & 8,110 & 4,840 & 3,010 & 1,770 & 1,290 & 1,000 & 680 & 530 & 380 & 240 & 21,850 \\
\hline 1962 & 5,401 & 6,790 & 3,716 & 1,945 & 1,110 & 756 & 673 & 462 & 329 & 397 & 21,579 \\
\hline 1963 & 5,787 & 4,181 & 4,963 & 2,500 & 1,153 & 651 & 432 & 383 & 280 & 181 & 20,511 \\
\hline 1964 & 5,122 & 4,493 & 2,887 & 3,015 & 1,523 & 683 & 396 & 250 & 240 & 192 & 18,801 \\
\hline 1965 & 6,872 & 3,952 & 3,169 & 1,830 & 1,581 & 796 & 377 & 217 & 129 & 141 & 19,064 \\
\hline 1966 & 8,184 & 5,373 & 2,823 & 2,002 & 929 & 687 & 350 & 175 & 116 & 72 & 20,711 \\
\hline 1967 & 9,261 & 6,100 & 3,547 & 1,740 & 1,098 & 483 & 345 & 207 & 101 & 74 & 22,956 \\
\hline 1968 & 6,729 & 6,872 & 4,082 & 2,024 & 924 & 548 & 240 & 137 & 115 & 52 & 21,723 \\
\hline 1969 & 5,794 & 4,680 & 3,826 & 2,030 & 925 & 413 & 246 & 128 & 63 & 63 & 18,168 \\
\hline 1970 & 5,379 & 4,399 & 2,960 & 1,744 & 752 & 312 & 172 & 97 & 50 & 14 & 15,879 \\
\hline 1971 & 5,907 & 3,886 & 2,902 & 1,573 & 715 & 372 & 165 & 108 & 62 & 31 & 15,721 \\
\hline 1972 & 4,775 & 4,212 & 2,348 & 1,522 & 784 & 367 & 202 & 96 & 70 & 40 & 14,416 \\
\hline 1973 & 2,089 & 3,187 & 2,393 & 1,233 & 739 & 374 & 194 & 108 & 51 & 42 & 10,410 \\
\hline 1974 & 1,278 & 1,342 & 1,755 & 1,424 & 690 & 358 & 177 & 90 & 54 & 22 & 7,190 \\
\hline 1975 & 1,354 & 922 & 777 & 761 & 611 & 238 & 125 & 53 & 24 & 18 & 4,883 \\
\hline 1976 & 2,659 & 973 & 520 & 322 & 271 & 178 & 75 & 33 & 22 & 8 & 5,061 \\
\hline
\end{tabular}

In order to derive estimates of the rates of inshore exploitation, it was necessary to calculate instantaneous fishing mortality rates by age-group for the offshore fishery and the numbers of cod remaining in the population at the end of the offshore fishery. The calculations are based on the assumption that most of the cod in the offshore fishery are taken during JanuaryJune in each year. 
TABLE 3. Estimates of total fishing mortality from cohort analysis and offshore fishing mortality (FO) by agegroup for cod in NAFO Div. 2J+3KL, 1961-76.

\begin{tabular}{|c|c|c|c|c|c|c|c|c|c|c|}
\hline \multirow[b]{2}{*}{ Year } & \multicolumn{10}{|c|}{ Fishing mortality estimates by age-group } \\
\hline & 4 & 5 & 6 & 7 & 8 & 9 & 10 & 11 & 12 & 13 \\
\hline \multicolumn{11}{|c|}{ A. Total fishing mortality } \\
\hline 1961 & 0.042 & 0.110 & 0.240 & 0.330 & 0.350 & 0.390 & 0.440 & 0.310 & 0.420 & 0.580 \\
\hline 1962 & 0.056 & 0.113 & 0.197 & 0.323 & 0.333 & 0.360 & 0.364 & 0.299 & 0.399 & 0.250 \\
\hline 1963 & 0.053 & 0.170 & 0.298 & 0.296 & 0.323 & 0.298 & 0.345 & 0.266 & 0.176 & 0.270 \\
\hline 1964 & 0.059 & 0.149 & 0.256 & 0.446 & 0.449 & 0.395 & 0.400 & 0.463 & 0.329 & 0.320 \\
\hline 1965 & 0.046 & 0.136 & 0.259 & 0.478 & 0.633 & 0.623 & 0.564 & 0.424 & 0.381 & 0.360 \\
\hline 1966 & 0.094 & 0.215 & 0.284 & 0.401 & 0.454 & 0.488 & 0.326 & 0.351 & 0.246 & 0.320 \\
\hline 1967 & 0.098 & 0.202 & 0.361 & 0.433 & 0.495 & 0.500 & 0.724 & 0.387 & 0.465 & 0.370 \\
\hline 1968 & 0.163 & 0.386 & 0.499 & 0.583 & 0.604 & 0.601 & 0.431 & 0.571 & 0.396 & 0.510 \\
\hline 1969 & 0.075 & 0.258 & 0.585 & 0.794 & 0.889 & 0.677 & 0.728 & 0.734 & 1.317 & 0.660 \\
\hline 1970 & 0.125 & 0.216 & 0.432 & 0.692 & 0.503 & 0.438 & 0.263 & 0.243 & 0.278 & 0.500 \\
\hline 1971 & 0.138 & 0.304 & 0.445 & 0.497 & 0.466 & 0.409 & 0.341 & 0.241 & 0.239 & 0.490 \\
\hline 1972 & 0.204 & 0.365 & 0.444 & 0.522 & 0.540 & 0.439 & 0.430 & 0.425 & 0.315 & 0.480 \\
\hline 1973 & 0.243 & 0.397 & 0.319 & 0.380 & 0.524 & 0.545 & 0.567 & 0.494 & 0.642 & 0.380 \\
\hline 1974 & 0.127 & 0.346 & 0.636 & 0.646 & 0.863 & 0.853 & 1.008 & 1.124 & 0.906 & 0.680 \\
\hline 1975 & 0.131 & 0.372 & 0.680 & 0.833 & 1.032 & 0.958 & 1.141 & 0.694 & 0.916 & 0.800 \\
\hline 1976 & 0.312 & 0.499 & 0.762 & 0.960 & 0.937 & 1.207 & 1.091 & 1.026 & 0.441 & 0.810 \\
\hline \multicolumn{11}{|c|}{ B. Offshore fishing mortality (FO) } \\
\hline 1961 & 0.027 & 0.065 & 0.175 & 0.261 & 0.289 & 0.326 & 0.364 & 0.252 & 0.338 & 0.457 \\
\hline 1962 & 0.037 & 0.070 & 0.152 & 0.240 & 0.261 & 0.270 & 0.280 & 0.222 & 0.287 & 0.200 \\
\hline 1963 & 0.038 & 0.118 & 0.210 & 0.214 & 0.217 & 0.207 & 0.238 & 0.196 & 0.127 & 0.192 \\
\hline 1964 & 0.034 & 0.102 & 0.196 & 0.353 & 0.361 & 0.278 & 0.303 & 0.342 & 0.243 & 0.250 \\
\hline 1965 & 0.029 & 0.099 & 0.206 & 0.391 & 0.493 & 0.513 & 0.413 & 0.324 & 0.258 & 0.261 \\
\hline 1966 & 0.069 & 0.171 & 0.222 & 0.331 & 0.369 & 0.369 & 0.244 & 0.208 & 0.141 & 0.194 \\
\hline 1967 & 0.079 & 0.163 & 0.295 & 0.363 & 0.401 & 0.400 & 0.526 & 0.293 & 0.303 & 0.266 \\
\hline 1968 & 0.122 & 0.315 & 0.426 & 0.504 & 0.518 & 0.524 & 0.345 & 0.437 & 0.306 & 0.333 \\
\hline 1969 & 0.049 & 0.185 & 0.497 & 0.683 & 0.751 & 0.561 & 0.651 & 0.523 & 1.014 & 0.548 \\
\hline 1970 & 0.089 & 0.169 & 0.349 & 0.595 & 0.435 & 0.368 & 0.187 & 0.178 & 0.170 & 0.261 \\
\hline 1971 & 0.116 & 0.247 & 0.387 & 0.423 & 0.388 & 0.336 & 0.270 & 0.198 & 0.215 & 0.548 \\
\hline 1972 & 0.153 & 0.303 & 0.369 & 0.444 & 0.452 & 0.364 & 0.354 & 0.337 & 0.252 & 0.033 \\
\hline 1973 & 0.186 & 0.326 & 0.284 & 0.333 & 0.453 & 0.450 & 0.474 & 0.408 & 0.506 & 0.064 \\
\hline 1974 & 0.064 & 0.257 & 0.541 & 0.568 & 0.739 & 0.735 & 0.864 & 0.972 & 0.775 & 0.004 \\
\hline 1975 & 0.053 & 0.254 & 0.534 & 0.685 & 0.881 & 0.761 & 0.864 & 0.554 & 0.680 & 0.633 \\
\hline 1976 & 0.215 & 0.298 & 0.521 & 0.671 & 0.689 & 0.956 & 0.811 & 0.652 & 0.307 & 0.483 \\
\hline
\end{tabular}

The instantaneous fishing mortality rate $(F O(a, t))$ for each age-group $a$ in the offshore fishery during the first half of year $t$ (Table 3B) was obtained by iteration from the relationship

$$
\frac{F O(a, t)(1-\exp (-(F O(a, t)+M / 2)))}{F O(a, t)+M / 2}=\frac{C O(a, t)}{N(a, t)}
$$

where

$M=$ instantaneous (annual) natural mortality coefficient, which was assumed to be constant for all ages and years and estimated to be about 0.2 (Pinhorn, 1975);

$\mathrm{CO}(\mathrm{a}, \mathrm{t})=$ catch in numbers at age $\mathrm{a}$ in the offshore fishery in year $t$

$N(a, t)=$ numbers at age $a$ in the population at the beginning of year $t$ (i.e. beginning of the offshore fishery).

Having derived the matrix $F O(a, t)$, the number of cod at each age present in the population at the end of the offshore fishery (i.e. 30 June) in each year $(\mathrm{NO}(a, t))$ was calculated from the formula

$$
N O(a, t)=N(a, t) \exp (-(F O(a, t)+M / 2))
$$

and the rate of inshore exploitation at age $a$ in year $t$ is given by

$$
\mathrm{I}(\mathrm{a}, \mathrm{t})=\mathrm{Cl}(\mathrm{a}, \mathrm{t}) / \mathrm{NO}(\mathrm{a}, \mathrm{t})
$$

where $\mathrm{Cl}(\mathrm{a}, \mathrm{t})=$ number of cod at age $\mathrm{a}$ caught in the inshore fishery in year $t$.

\section{Results and Discussion}

The estimated rates of inshore exploitation (Table 4) by the method described above depend on two basic assumptions: (a) the offshore and inshore fisheries occur during January-June and July-December of each year respectively, and (b) the inshore migration of cod occurs instantaneously on 1 July in each year. To test the validity of the first assumption, the offshore and inshore catches were summarized by month for 
TABLE 4. Estimated rates of inshore exploitation by age-group for cod in NAFO Div. 2J+3KL, 1961-76. (Overall averages derived from weighting inshore exploitation rates by population numbers.)

\begin{tabular}{|c|c|c|c|c|c|c|c|c|c|c|}
\hline \multirow[b]{2}{*}{ Year } & \multicolumn{9}{|c|}{ Rates of inshore exploitation by age-group } & \multirow{2}{*}{$\begin{array}{c}\text { Overall } \\
\text { average }^{\mathrm{a}}\end{array}$} \\
\hline & 5 & 6 & 7 & 8 & 9 & 10 & 11 & 12 & 13 & \\
\hline 1961 & 0.041 & 0.055 & 0.051 & 0.045 & 0.043 & 0.055 & 0.041 & 0.064 & 0.097 & 0.048 \\
\hline 1962 & 0.039 & 0.036 & 0.066 & 0.051 & 0.070 & 0.063 & 0.060 & 0.085 & 0.040 & 0.045 \\
\hline 1963 & 0.044 & 0.073 & 0.066 & 0.087 & 0.075 & 0.087 & 0.056 & 0.042 & 0.063 & 0.063 \\
\hline 1964 & 0.041 & 0.045 & 0.064 & 0.060 & 0.093 & 0.071 & 0.095 & 0.070 & 0.056 & 0.050 \\
\hline 1965 & 0.038 & 0.042 & 0.050 & 0.094 & 0.064 & 0.109 & 0.077 & 0.109 & 0.079 & 0.051 \\
\hline 1966 & 0.034 & 0.048 & 0.047 & 0.047 & 0.088 & 0.065 & 0.119 & 0.089 & 0.118 & 0.046 \\
\hline 1967 & 0.029 & 0.044 & 0.043 & 0.068 & 0.053 & 0.141 & 0.060 & 0.124 & 0.087 & 0.041 \\
\hline 1968 & 0.047 & 0.039 & 0.039 & 0.044 & 0.048 & 0.043 & 0.091 & 0.060 & 0.145 & 0.045 \\
\hline 1969 & 0.060 & 0.048 & 0.048 & 0.064 & 0.065 & 0.055 & 0.096 & 0.160 & 0.084 & 0.056 \\
\hline 1970 & 0.037 & 0.056 & 0.045 & 0.034 & 0.043 & 0.061 & 0.068 & 0.065 & 0.174 & 0.045 \\
\hline 1971 & 0.041 & 0.030 & 0.041 & 0.049 & 0.047 & 0.053 & 0.037 & 0.046 & 0.102 & 0.039 \\
\hline 1972 & 0.040 & 0.048 & 0.042 & 0.051 & 0.048 & 0.050 & 0.059 & 0.042 & 0.083 & 0.044 \\
\hline 1973 & 0.046 & 0.017 & 0.023 & 0.035 & 0.056 & 0.051 & 0.058 & 0.083 & 0.045 & 0.034 \\
\hline 1974 & 0.069 & 0.049 & 0.029 & 0.052 & 0.047 & 0.054 & 0.041 & 0.043 & 0.052 & 0.050 \\
\hline 1975 & 0.095 & 0.097 & 0.078 & 0.056 & 0.117 & 0.155 & 0.087 & 0.117 & 0.045 & 0.090 \\
\hline 1976 & 0.163 & 0.176 & 0.193 & 0.152 & 0.124 & 0.156 & 0.229 & 0.094 & 0.264 & 0.167 \\
\hline Mean & 0.054 & 0.056 & 0.058 & 0.062 & 0.068 & 0.079 & 0.079 & 0.081 & 0.096 & \\
\hline
\end{tabular}

averall average for $1961-74$ (and 95\% confidence limits) $=0.047(0.042-0.051)$.

the 1961-79 period. During this period, the proportion of the offshore catch taken during January-June varied between $53 \%$ (1962) and 86\% (1973) with an overall average of $71 \%$. The trend during 1961-79 was toward a larger proportion of the offshore catch being taken in January-June in the 1970's (74-86\%) than in the 1960's $(53-76 \%)$. The proportion of the inshore catch taken during July-December varied between 54\% (1971) and $86 \%$ (1974) with an overall average of $74 \%$. In fact, virtually the entire inshore catch throughout the 1961-79 period was taken during June-December. Unfortunately, the data base is not adequate to consider the problem by month and/or division, because the sampling data collected during the period do not allow the numbers caught by age-group to be derived by month and division for every year. It is obvious that the second assumption regarding migration is not valid because all cod migrating inshore do not do so on 1 July of each year. Data do not exist to measure the degree of deviation from this assumption, but the deviation should be minimal because inshore migration generally occurs rather quickly in June (Templeman, 1979).

The basic assumption that all offshore fishing occurred before 1 July and all inshore fishing occurred after 30 June is violated to different degrees during the period under investigation. To evaluate the effect of such violations on the calculation of rates of inshore exploitation, the proportion $(P)$ of the nominal catch of cod by the offshore fleet in January-June was assumed to be equal to the proportion of the numbers of cod caught by the offshore fleet $(\mathrm{CO}(\mathrm{t}))$ during the same period for all age-groups combined. Then

$$
\frac{C O(t) P}{N(t)}=\frac{F O^{\prime}(t)\left(1-\exp \left(-\left(F O^{\prime}(t)+M / 2\right)\right)\right)}{F O^{\prime}(t)+M / 2}
$$

where $F O^{\prime}(t)=$ true offshore fishing mortality rate for the January-June period.

Application of this equation to data for the worse year (1962) when only $53 \%$ of the offshore catch was taken in January-June indicated only an $8 \%$ difference in the calculated rates of inshore exploitation for all age-groups combined. Therefore, the violation of this assumption has no significant effect on the results of the analysis.

The "rate of inshore exploitation" used in this paper (Equation 3) is the ratio of the number of cod taken in the inshore fishery during July-December in year $t$ to the number present at the end of the offshore fishery on 30 June in year $t$ (Table 4). It is not in fact the "true" rate of exploitation in the inshore fishery as usually defined (Ricker, 1975, p. 5), because it can be easily shown that, if two fisheries on the same stock occur consecutively and if only a portion of the total stock is available to the second fishery (which closely approximates the situation described in this paper), the sum of the fishing mortalities and the sum of the rates of exploitation (calculated separately for each fishery in relation to the stock at the beginning of the year) both exceed the fishing mortality and the rate of exploitation relevant to the total fishery in that year. The true fishing mortality and the rate of exploitation for the inshore fishery in a given year must be calculated in relation to the stock present at the beginning of the inshore fishery in that year and not from the beginning of the calendar year. In this case, the "rate of inshore exploitation" is the product of the proportion of cod migrating to coastal waters (migration factor) and the proportion of those migrants which are actually caught in the inshore fishery (true rate of inshore exploitation) in a given year. 
Average rates of inshore exploitation for each year (Table 4) do not include age-group 4 because of very low fishing mortalities for this age-group (Table 3 ) and the inherent bias associated with discarding of small fish, both having a disproportionate effect on the average rates due to the large numbers of age-group 4 fish in the population. The averages for age-groups 5-13 showed no significant trends during 1961-74 but increased substantially during 1975-76. These high values may have resulted from increased fishing mortality in coastal waters or increased rate of inshore migration or a combination of both, but no data exist to determine which of the two factors was more important.

Examination of the average rates by age-groups (Table 4) revealed a regular increase from age 5 to 13 $\left(r^{2}=0.97, P<0.001\right)$. It is well known that most fishing gears, including those used in the inshore fishery, exhibit a pattern of selectivity such that older fish up to a certain age are progressively more susceptible to capture than younger fish (Beverton and Holt, 1957). Also, there is evidence that younger and smaller cod of the Labrador-East Newfoundland stock migrate to shallow coastal and bank areas as the surface and near-surface water becomes warmer in summer, whereas older and larger fish migrate to the fringes of the coastal shelves below the cold intermediate water layer (Templeman, 1979). Therefore, the increasing trend in the averages with age may have resulted from a combination of differential selectivity and migration with age.

The "rate of inshore exploitation", as defined in this paper, is really a measure of success of fishing in coastal waters, in that it is the product of the proportion of cod migrating inshore and the proportion of the inshore population that is actually caught in the inshore fishery. The implication is that, on the average, at least $4.7 \%$ of the total population in the offshore area must have migrated inshore annually during 1961-74, but the upper limit may be $100 \%$. In fact, the estimates show that $17 \%$ or more of the stock migrated inshore in 1976 (Table 4).

The success of fishing in inshore waters in a given year, as measured by the rates of inshore exploitation, may be influenced by many factors (Templeman, 1966). Among the most important of these are inshore fishing effort, cod biomass, capelin biomass and environmental conditions, chiefly temperature. For a given availability of cod in inshore waters, higher fishing effort results in higher catches. Also, the size of the cod biomass may affect the extent of inshore migration, the rate of migration varying with the level of biomass. For example, when abundance of cod is low, a larger proportion of the population could be sustained by the food supply in offshore areas and fewer would migrate to inshore waters in search of food. The main food of cod in summer is capelin (Mallotus villosus) and the inshore migration of cod in early summer is presumed to be a feeding migration for capelin (Templeman, 1965). Therefore, the abundance of capelin and the extent to which they migrate to inshore areas probably affect the success of the inshore fishery. Also, in the inshore areas of Div. $2 \mathrm{~J}+3 \mathrm{KL}$, cod are found in summer usually where water temperatures are $0^{\circ}$ to $5^{\circ} \mathrm{C}$ (Templeman and May, 1965). Therefore, the extent to which water of this temperature range exists in inshore areas probably influences the success of inshore fishing, but the effect is likely to be greater for codtraps than for gillnets and longlines. A detailed account of the effect of various factors on the success of the inshore fishery by various gears was given by Templeman (1966).

Akenhead et al. (1982), using a gross index of inshore availability of cod during $1972-80$ by dividing the inshore cod catch in a given year by the estimated biomass of cod at the beginning of the year, found that capelin biomass and temperature were significant variables influencing the availability of cod inshore. However, the authors had severe reservations about the interpretation of the correlation for a variety of reasons listed in their paper. Because estimates of capelin abundance before 1972 do not exist and the data series used in the present analysis extends only to 1976, no correlation of capelin biomass with rates of inshore exploitation was attempted in this paper.

In order to estimate the proportion of cod migrating to inshore waters each year from rates of inshore exploitation, it is necessary to know the ratio of the numbers of cod caught inshore to the numbers present in inshore waters. The traditional technique of calculating partial fishing mortalities from ratios of catches in the respective fisheries (ICES, 1981) is not applicable in this case because the fisheries generally do not overlap in time, and, in any case, only a portion of the cod remaining from the offshore fishery is available to the inshore fishery because not all cod migrate inshore. Therefore, some other means of estimating fishing mortalities for the inshore area must be found. One such method would be to tag cod on their shoreward migration at a time when it is reasonably certain that these are the cod which will contribute to the inshore fishery. Recaptures in the inshore fishery in the same year would provide the basis for estimating the proportion caught of the cod actually present in inshore waters. Migration rates could be calculated from these estimates and the rates of inshore exploitation derived for the tagging years from cohort analysis by the method outlined in this paper. Research along these lines is presently underway. 


\section{Acknowledgements}

I am indebted to R. Wells for use of unpublished data on the breakdown of catches by age-group into offshore and inshore components and for critically reviewing a draft of the manuscript, and to $\mathrm{S}$. Gavaris who also reviwed the manuscript and provided helpful suggestions and criticisms during the preparation of the final version.

\section{References}

AKENHEAD, S. A., J. CARSCADDEN, H. LEAR, G. R. LILLY, and R. WELLS. 1982. Cod-capelin interactions off northeast Newfoundland and Labrador. Can. Spec. Publ. Fish. Aquat. Soi., 59: 141-148. BEVERTON, R. J. H., and S. J. HOLT. 1957. On the dynamics of exploited fish populations. Fish. Invest. Lond., Ser. 2, 19, $533 \mathrm{p}$. HODDER, V. M. 1965. Trends in the cod fishery off the east coast of Newfoundland and Labrador. ICNAF Res. Bull., 2: 31-41.

ICES. MS 1981. Report of ad hoc working group on use of effort data in assessments. ICES C.M., Doc. No. G:5, 65 p.

LEAR, W. H. MS 1982. Discrimination of the cod stock complex in
Divisions $2 \mathrm{~J}+3 \mathrm{KL}$ based on tagging. NAFO SCR Doc., No. 89 , Serial No. N598, $33 \mathrm{p}$.

PINHORN, A. T. 1975. Estimates of natural mortality for the cod stock complex in ICNAF Divisions $2 \mathrm{~J}, 3 \mathrm{~K}$ and $3 \mathrm{~L}$. ICNAF Res. Bull., 11: $31-36$.

POPE, J. G. 1972. An investigation of the accuracy of virtual population analysis using cohort analysis. ICNAF Res. Bull., 9: 65-74.

RICKER, W. E. 1975. Computation and interpretation of biological siatistics of fish populations. Bull. Fish. Res. Bd. Canada, 191, $382 \mathrm{p}$.

TEMPLEMAN, W. 1962. Divisions of cod stocks in the Northwest Atlantic. ICNAF Redbook, 1962, Part III: 79-123.

1965. Some instances of cod and haddock behaviour and concentrations in the Newfoundland and Labrador areas in relation to food. ICNAF Spec. Publ., 6: 449-461.

1966. Marine resources of Newfoundland. Bull. Fish. Res. Bd. Canada, 154, $170 \mathrm{p}$

1979. Migrations and intermingling of stocks of Atlantic cod, Gadus morhua, of the Newfoundland and adjacent areas from tagging in 1962-66. ICNAF Res. Bull., 14: 5-50.

TEMPLEMAN, W., and A. M. FLEMING. 1956. The Bonavista longlining experiment, 1950-53. Bull. Fish. Res. Bd. Canada, 109, 55 p.

TEMPLEMAN, W., and A. W. MAY. 1965. Research vessel catches of cod in the Hamilton Inlet Bank area in relation to depth and temperature. ICNAF Spec. Publ., 6: 149-165.

WELLS, R. MS 1981. Status in 1980 of the cod stock in Divisions 2J+3KL. NAFO SCR Doc., No. 66, Serial No. N350, 13 p. 